JURNAL RESPIRASI

JR

Vol. 5 No. 1 Januari 2019

\title{
Seorang Wanita Mengalami Aspirasi Barium dengan Komplikasi Pneumonia
}

\author{
Isnin Anang Marhana, Adhari Ajipurnomo \\ Departemen Pulmonologi dan Ilmu Kedokteran Respirasi, Fakultas Kedokteran Universitas Airlangga/RSUD Dr. Soetomo
}

\begin{abstract}
Background; Barium aspiration is one of rare major complication of esophagography. $40 \%$ cases of aspiration pneumonia occur without clinical symptoms and the other $30 \%$ results in deaths.

Case. A 62-years-old female choked some barium liquid when performing esophagography procedure. We found ronchi on lower left haemithorax and granuler hiperdensity pattern on left paracardial from chest x-ray photo. Eight days later, patient suffered the clinical symptoms of infection and from chest x-ray photo we found infiltrate and rest of barium. We found Burcholderia Gladioli and Pseudomonas containing 1,22 $\mathrm{mg} / \mathrm{L}$ of barium from microbiology examination of bronchus lavage.

Discussion. Barium aspiration was one of major complication in esophagography procedure in extreme age. Chest x-ray and Computed Tomography can help to diagnose and evaluate in this case. Quantity and density of barium liquid could affect the prognosis of this case. Oropharingeal which containing a number of pathogen can cause pneumonia as disease complication. There was still no guideline for barium aspiration management, but bronchoscopy was recommended by many studies.

Conclusion. Pneumonia was one of barium aspiration complication. Bronchoscopy was recommended procedure as diagnose dan therapy tool for barium aspiration case. Anaerob activity antibiotic should be given when pneumonia was suspected.
\end{abstract}

Keyword: Barium, Pneumonia aspiration, Esophagography complication, Nronchoscopy

Correspondence: Isnin Anang Marhana, Departemen Pulmonologi dan Ilmu Kedokteran Respirasi, Fakultas Kedokteran Universitas Airlangga/RSUD Dr. Soetomo. Jl. Mayjen Prof. Dr. Moestopo 6-8 Surabaya 60286 Email: marhanadr@yahoo.com

\section{PENDAHULUAN}

Pneumonia adalah keradangan parenkim paru dimana asinus terisi dengan cairan radang, dengan atau tanpa disertai infiltrasi dari sel radang ke dalam interstitium. ${ }^{1}$ Salah satu klasifikasi pneumonia menurut klinis dan epidemiologis adalah pneumonia aspirasi. Aspirasi didefinisikan sebagai terhisapnya atau masuknya benda atau cairan orofaringeal atau lambung ke dalam laring atau saluran pernapasan di bawahnya. ${ }^{2}$ Angka insidensi penumonia aspirasi sulit untuk ditentukan karena banyak kasus dari community acquired pneumonia (CAP) atau hospital-acquired pneumonia (HAP) yang disebabkan oleh aspirasi yang tidak terdiagnosa. Di Indonesia sendiri masih belum ada data pasti yang menunjukkan angka insidensi dari pneumonia aspirasi ini. Beberapa studi menunjukkan pneumonia aspirasi kemungkinan menyebabkan 5-15\% dari semua kasus
CAP. Di Amerika Serikat, pneumonia aspirasi merupakan penyebab kematian terbesar pada pasien dengan disfagia yaitu sekitar 300.000 sampai 600.000 setiap tahunnya. ${ }^{3}$ Studi lain menunjukkan bahwa sekitar 8 dari 1000 pasien yang dirawat inap di rumah sakit mengalami pneumonia aspirasi dan 40\% tidak menunjukkan gejala klinis. ${ }^{4}$

Prosedur esofagografi yang menggunakan bahan kontras barium merupakan prosedur diagnostik yang rutin dilakukan terhadap pasien yang mengalami disfagia yang masih belum diketahui dengan jelas penyebabnya. Salah satu komplikasi mayor dari tindakan tersebut adalah aspirasi dari bahan kontras barium. Komplikasi aspirasi barium sangat jarang terjadi sehingga tidak ada data insidensi yang pasti. ${ }^{5}$ Sebuah studi menunjukkan angka kematian yang disebabkan oleh aspirasi barium sebesar 30\% dan lebih dari 50\% pasien mengalami syok atau apnea, penumonia sekunder dan distress napas. ${ }^{6}$

Berikut ini akan kami sampaikan laporan kasus seorang perempuan dengan pneumonitis aspirasi bahan 


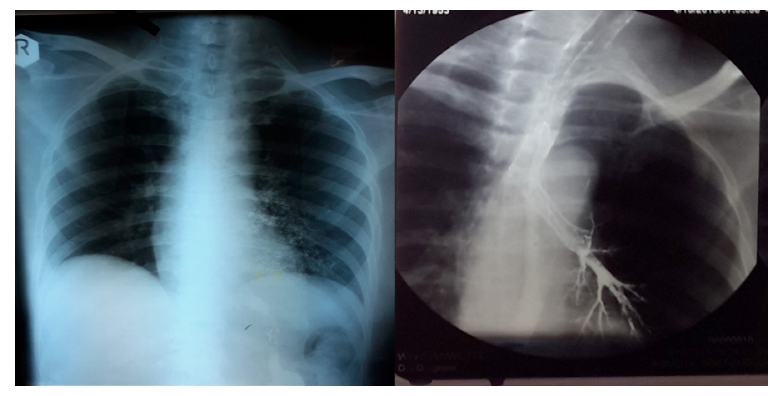

Gambar 1. Foto toraks pasien saat pertama datang mengesankan kontras post esofagografi

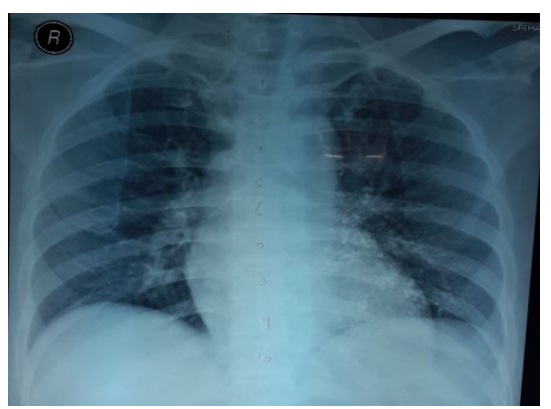

Gambar 2. Foto toraks pasien saat kontrol mengesankan masih terdapat sisa kontras

kimia berupa barium pada saat dilakukan tindakan esofagografi dan mengalami komplikasi pneumonia sekunder yang dalam perjalanan penyakitnya mengalami perbaikan setelah dilakukan tindakan bronkoskopi dan antibiotik yang tepat.

\section{KASUS}

Seorang wanita usia 62 tahun dengan keluhan utama batuk 1 hari. Batuk tidak berdahak. Pasien dengan riwayat menjalani tindakan esofagografi dengan kontras barium akibat keluhan susah menelan. Pada saat pasien diminta untuk menelan bahan kontras, pasien batuk dan tersedak bahan kontras. Nyeri ulu hati dan mual sejak 2 bulan yang lalu, kadang disertai muntah setelah menelan makanan. Penurunan nafsu makan dan berat badan dirasakan sekitar $3 \mathrm{~kg}$ dalam 2 bulan terakhir. Pasien tidak rutin menggosok gigi

Pemeriksaan fisik paru menemukan ronki pada $1 / 3$ bawah paru kiri sedangkan. Pemeriksaan radiologi toraks menunjukkan gambaran corak granuler di parakardial kiri yang mengesankan kontras post esofagografi (aspirasi) (Gambar 1).

Pada perjalanan penyakitnya, delapan hari kemudian pasien mengeluh batuk berdahak warna putih disertai demam $\left(38^{\circ} \mathrm{C}\right)$ dengan pemeriksaan fisik menunjukkan ronkhi di 1/3 bawah paru kanan dan kiri. Pemeriksaan penunjang pun menunjukkan perubahan, yaitu pada pemeriksaan laboratorium darah didapatkan leukositosis $12.820 / \mathrm{mm} 3$, dan pemeriksaan foto toraks evaluasi didapatkan multipel bayangan radiopaque di paracardial-parahiler kiri terproyeksi setinggi VTh 5-9

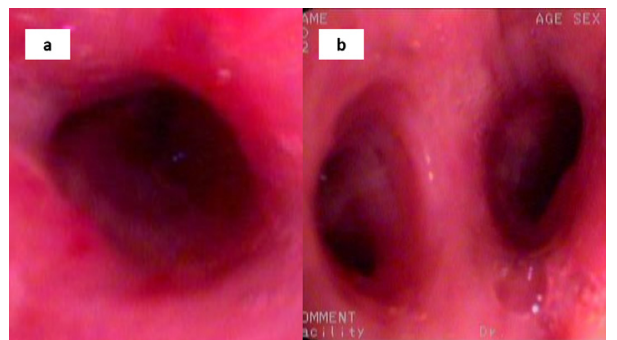

Gambar 3. Bronkoskopi A. Lingula, B. Lingula

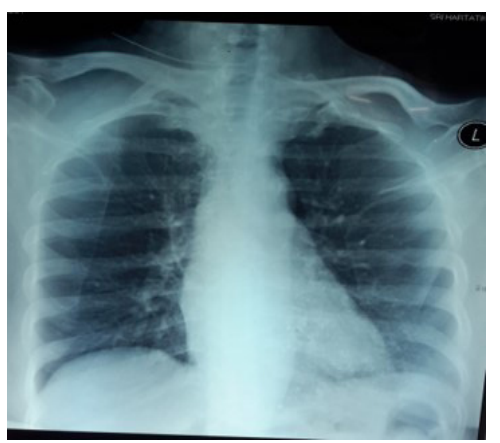

Gambar 4. Foto toraks pasien saat kontrol mengesankan sisa kontras yang sudah berkurang

sisi kiri yang mengesankan sisa kontras (Gambar 2).

Delapan hari kemudian dilakukan bronkoskopi untuk penyedotan sisa kontras barium di sistem bronkoalveolar dan Pasien mendapatkan antibiotik levofloxacin. Hasil pemeriksaan bronkoskopi menunjukkan gambaran hipersekresi pada lobus inferior paru kanan dan bronkus utama paru kiri serta penyempitan lumen lingula dan lobus inferior paru kiri yang disebabkan oleh edema mukosa (Gambar 3). Dari hasil pemeriksaan laboratorium dari cairan BAL ditemukan bakteri Gram negatif Pseudomonas spp serta kadar barium positif 1,22 mg/L.

Tujuh hari kemudian pasien kontrol dengan gejala respirasi yang berkurang dengan hasil laboratorium darah leukosit yang normal yaitu 7.610/mm3. Pada pemeriksaan foto toraks evaluasi tidak tampak gambaran pneumonia dan masih tampak sisa kontras yang berkurang di paracardial-parahiler kiri (Gambar 4).

\section{PEMBAHASAN}

Esofagografi dengan menelan bahan kontras barium merupakan metode diagnostik yang umum dilakukan untuk mengetahui struktur anatomis dan gangguan fungsional pada saluran pencernaan bagian atas dan mencari penyebab gastroesophageal reflux. Selain itu, metode ini juga sangat baik untuk mengetahui mekanisme menelan dari pasien yang mengalami gangguan menelan. ${ }^{7}$

Aspirasi barium merupakan komplikasi yang jarang terjadi pada metode esofagografi. ${ }^{5}$ Faktor yang dapat meningkatkan resiko terjadinya aspirasi barium adalah pada kondisi gangguan fungsional menelan dan perubahan struktur anatomi dari esofagus dan orofaring. 
Kondisi tersebut umumnya ditemukan pada pasien dengan gangguan susunan saraf pusat seperti penyakit Parkinson dan cerebral palsy, gastroesophageal reflux, usia yang ekstrim (sangat tua atau sangat muda), fistula broncho-esophageal, peminum alkohol, kanker pada kepala dan leher, dan penyakit psikis. ${ }^{8}$ Pada kasus ini pasien berusia 62 tahun dengan gejala disfagia tanpa disertai dengan gejala gangguan saraf atau kecurigaan kanker pada kepala dan leher.

Barium sulfat merupakan suatu bahan kontras yang mengandung barium dengan nomer atom yang tinggi yaitu 56, sehingga dapat terlihat hiperdens atau opasitas pada pemeriksaan radiologi. ${ }^{8}$ Selain itu barium sulfat juga memiliki sifat inert, larut dalam air, tidak diserap, dan relatif tidak menimbulkan iritasi, sehingga jarang menimbulkan reaksi inflamasi. ${ }^{9}$ Karena sifatnya tersebut maka barium sulfat digunakan oleh Nelson dkk (1964) sebagai bahan kontras dengan kepekatan 50\% untuk prosedur diagnostik bronkografi. ${ }^{10}$

Aspirasi barium terjadi bila bahan kontras barium sulfat masuk ke saluran pernapasan. Gejala awal pada aspirasi barium adalah batuk. Gejala lain atau tanda infeksi seperti demam, batuk yang memberat dan sesak napas berlangsung kemudian bila telah terjadi komplikasi infeksi bakteri.

Jumlah kontras barium yang masuk ke saluran pernapasan mempengaruhi prognosis penyakit. Semakin banyak jumlah kontras yang masuk ke saluran napas maka akan menyumbat saluran napas dan mengisi ruang alveoli yang menyebabkan gangguan fungsi pernapasan, sehingga pasien mengeluh sesak napas. ${ }^{8}$

Untuk kondisi yang akut, foto X-ray toraks merupakan pemeriksaan terbaik untuk mendiagnosa aspirasi barium selain data yang diperoleh dari anamnesa berupa riwayat tersedak atau batuk pada saat menelan bahan kontras. ${ }^{11}$ Pemeriksaan High Resolution Computed Tomography (HRCT) dilakukan pada kasus berat untuk mengetahui perkembangan penyakit dari aspirasi barium yang berat. ${ }^{11}$

Posisi pasien pada saat terjadi aspirasi barium juga menentukan penyebaran daerah hiperdens pada foto toraks. Area hiperdens tampak pada segmen basal dari lobus inferior bila pasien pada posisi tegak, lobus medius bila pasien posisi lurus kedepan atau membungkuk seperti pada saat muntah atau batuk dan segmen posterior lobus superior bila pasien posisi terlentang. ${ }^{11}$ Pada kasus ini posisi pasien saat aspirasi adalah posisi tegak sehingga ditemukan multipel opasitas pada lobus inferior yang sebagian besar pada paru sebelah kiri.

Pada saat proses menelan bahan kontras barium sulfat dan terjadi aspirasi, maka yang masuk ke saluran napas dapat berupa bahan kontras barium sulfat atau dapat bercampur dengan isi lambung atau sekret orofaring. ${ }^{9}$ Banyaknya volume cairan yang masuk ke dalam saluran pernapasan adalah penting dalam menentukan keparahan dan prognosis dari aspirasi. ${ }^{10}$ Sifat barium sulfat yang "inert" atau tidak mengiritasi umumnya tidak menyebabkan reaksi inflamasi atau kerusakan paru. ${ }^{9}$ Pneumonitis aspirasi terjadi ketika bahan aspirat berasal dari asam lambung sehingga terjadi kerusakan saluran napas atau paru. ${ }^{12}$

Ketika aspirasi barium sulfat terjadi, tubuh memiliki mekanisme pertahanan untuk membersihkan kontras barium sulfat dalam saluran pernapasan yang bersifat lambat. ${ }^{13}$ Sesaat setelah tersedak, tubuh merespon dengan reflek batuk untuk mengeluarkan barium sulfat dari saluran pernapasan. Selain itu terdapat mekanisme mucociliary escalator yaitu mekanisme dari epitel silia yang melapisi saluran napas yang bergerak, mengeluarkan bahan kontras bersamaan dengan lendir atau mukus yang melapisi saluran napas dan diikuti dengan refleks batuk atau menelan. ${ }^{1}$ Partikel barium yang terakumulasi atau yang masuk ke ruang alveoli difagosit oleh makrofag alveolar. Barium akan tetap di dalam makrofag alveolar sampai terjadi kematian oleh alveolar karena umurnya, selanjutnya barium akan keluar dan difagosit lagi oleh makrofag lain. Makrofag dengan barium didalamnya dapat bermigrasi ke jaringan limfoid yang selanjutnya menuju ke kelenjar getah bening mediastinum atau dapat juga bermigrasi ke bronkiolus yang selanjutnya dapat keluar dari saluran napas melalui mekanisme mucociliary escalator. ${ }^{14}$ Jumlah aspirasi barium sulfat yang besar dapat menyebabkan partikel barium melewati epitel alveoli dan masuk ke dalam ruang intertitial dan dapat menyebabkan fibrosis dalam jangka panjang. ${ }^{13}$ Fibrosis terjadi karena makrofag yang memfagosit barium di intertitial mengeluarkan sitokin TGF, PDGF, TNF dan IL-1 yang menyebabkan proliferasi fibroblas sehingga terjadi fibrosis. ${ }^{11,15}$ Fibrosis dapat terjadi dalam jangka panjang dan dapat ditemukan melalui pemeriksaan HRCT. ${ }^{11}$

Tidak ada data pasti yang menyebutkan jumlah barium yang dapat menyebabkan gangguan pernapasan atau morbiditas pada penderita. Jumlah aspirasi barium yang sedikit tidak menimbulkan efek atau gejala gangguan napas yang berarti pada pasien, seperti pada kasus ini. Tetapi bila jumlah aspirasi barium besar dengan kepekatan tinggi (100\%) dapat menyebabkan obstruksi dan mengganggu proses difusi gas dalam alveoli. Hal ini disebabkan karena semakin banyak jumlah barium yang mengisi ruang alveoli akan menimbulkan efek shunt dan mengganggu ketidakseimbangan rasio ventilasi/perfusi (V/Q) dengan resiko hipoksemia sampai gagal napas dan membuat pasien dalam kondisi mengancam nyawa. ${ }^{16}$ Pada sediaan kontras dengan kepekatan yang tinggi (250\%) seperti pada $E-Z-H D$ yang memiliki partikel besar, heterogenitas ukuran, bentuk dan keteraturan partikel membuatnya bertahan lebih lama dalam saluran napas kecil yang dapat menimbulkan reaksi inflamasi lokal. ${ }^{17}$ Reaksi hipersensitivitas juga dapat timbul oleh karena bahan campuran tambahan seperti sodium sitrat pada sediaan kontras barium komersial. ${ }^{17}$

Pneumonia aspirasi adalah keradangan paru yang disebabkan oleh masuknya atau terhisapnya sekret 
orofaringeal yang mengandung koloni bakteri patogen ke saluran napas bagian bawah. ${ }^{18}$ Resiko aspirasi sekret orofaringeal yang menyebabkan pneumonia aspirasi semakin meningkat pada kelompok umur yang semakin tua, karena insidensi disfagia dan gastroesophageal reflux semakin meningkat. Data tambahan dari suatu studi menunjukkan bahwa pada pasien tua, perilaku menjaga kebersihan mulut semakin rendah, sehingga dapat menimbulkan kolonisasi bakteri patogen saluran napas pada sekret orofaringeal seperti enterobacteriaceae, pseudomonas aeruginosa dan staphylococcus aureus. ${ }^{19}$ Pneumonia aspirasi dapat menunjukkan gejala infeksi pernapasan seperti batuk, demam dan sesak napas serta ditemukan infiltrat pada paru yang terinfeksi pada gambaran foto toraks.

Pada kasus ini pasien mengalami aspirasi kontras barium sulfat pada saat dilakukan esofagografi. Satu minggu kemudian pasien mengeluh batuk dan didapatkan demam yang menandakan suatu proses inflamasi sedang terjadi. Pemeriksaan laboratorium menunjukkan tanda infeksi serta dari gambaran radiologis didapatkan infiltrat pada parahilar dan parakardial kanan dan kiri. Hal ini menunjukkan bahwa pasien mengalami komplikasi berupa pneumonia aspirasi karena memiliki riwayat tersedak. Pneumonia tersebut dapat disebabkan oleh aspirasi sekret orofaringeal bercampur dengan aspirasi kontras yang telah terdapat kolonisasi bakteri patogen respirasi di dalamnya. Dari anamnesa didapatkan data bahwa pasien mengalami disfagia sejak lama dan tidak rutin menggosok gigi.

Tidak ada pedoman baku untuk menatalaksana pasien yang mengalami aspirasi barium. Manajemen aspirasi barium sangat tergantung pada gejala, kondisi klinis pasien dan fasilitas yang tersedia. ${ }^{20}$ Jumlah kontras barium yang masuk ke saluran pernapasan mempengaruhi keparahan dan prognosis penyakit yang diderita. Jumlah kontras yang sedikit tidak menimbulkan gangguan pernapasan yang berarti. Tetapi jumlah kontras yang banyak dapat menyebabkan gangguan proses difusi oksigen. Hal ini disebabkan karena jumlah kontras barium yang banyak atau semakin pekat tersebut dapat menyumbat atau obstruksi saluran pernapasan sehingga sesaat setelah pasien mengalami aspirasi barium. Pasien dianjurkan untuk dilakukan pemeriksaan analisa gas darah. ${ }^{8}$ Pasien yang mengeluh sesak hebat dan terjadi distress napas mengarah pada gagal napas, sehingga perlu dipertimbangkan untuk dilakukan intubasi atau penggunaan alat bantu napas ventilator dan perawatan di ICU.

Bronkoskopi sangat dianjurkan pada kondisi aspirasi barium dengan hipoksemia dan sesak yang hebat. ${ }^{21}$ Tujuan dari bronkoskopi adalah menyedot sebanyak mungkin bahan kontras yang terdapat dalam saluran bronko-alveolar dan untuk mengambil sampel untuk pemeriksaan mikrobiologi. Broncho-alveolar lavage sangat tidak dianjurkan karena resiko penyebaran dari kontras barium pada sisi yang sehat. ${ }^{8}$ Bila dicurigai telah terjadi infeksi bakteri maka dianjurkan untuk memberikan antibiotik empiris selama menunggu hasil pemeriksaan mikrobiologi dan uji kepekaan antibiotik. Tammi dkk merekomendasikan pemberian antibiotik dengan aktivitas mematikan bakteri anaerob bila dicurigai telah terjadi infeksi yang diakibatkan oleh masuknya cairan isi lambung pada saluran napas atau pneumonitis aspirasi. ${ }^{8}$ Pemberian antibiotik pada aspirasi barium tanpa komplikasi untuk tujuan profilaksis ataupun pada pasien dengan gejala respirasi kurang dari 48 jam sangat tidak dianjurkan, karena dapat menyebabkan resistensi selektif pada mikroorganisme respirasi. ${ }^{18}$ Pemberian antibiotik dengan broad-spectrum dipertimbangkan pada pasien dengan aspirasi barium yang tidak mengalami perbaikan klinis lebih dari 48 jam dan telah terjadi infeksi sekunder. ${ }^{18}$

Fisioterapi dada dapat dilakukan pada aspirasi barium dan berperan untuk mempercepat pembersihan sisa barium yang ada di dalam paru dan untuk mencegah terbentuknya fibrosis paru dalam jangka panjang. ${ }^{20}$ Pada kasus ini, pasien telah dilakukan FOB dan diberikan antibiotik empiris Levofloxacin dengan evaluasi klinis, laboratoris, dan radiologis yang membaik. Pasien tidak dilakukan fisioterapi dada karena dari evaluasi gambaran radiologis tanggal 5 Mei 2015 tampak sisa kontras yang minimal.

Beberapa hal dapat dilakukan untuk mencegah atau menurunkan resiko aspirasi pada saat dilakukan pemeriksaan esofagofrafi dengan bahan kontras. Pasien diposisikan secara tegak lurus dengan duduk dan sesaat setelah menelan kontras, pasien diminta untuk memutar kepala ke samping atau menunduk sampai dagu menyentuh leher untuk mencegah aspirasi barium. ${ }^{22}$ Pemberian obat anti-muntah seperti domperidone atau omeprazole dapat bermanfaat sebelum dilakukan pemeriksaan esofagografi dengan kontras. Pemilihan bahan kontras dan komposisi yang tepat untuk mencapai tingkat kepekatan yang rendah sehingga memudahkan proses menelan kontras. ${ }^{5}$ Beberapa peneliti menganjurkan teknik pemeriksaan baru yang dimodifikasi dengan metode video-fluoroscopy atau fiber optic endoscopic untuk mengetahui kelainan anatomi dan fisiologi dari orofaring dan esofagus. ${ }^{20}$

\section{Komplikasi dan Prognosis}

Prognosis pasien dengan aspirasi barium sangat bervariasi tergantung kondisi klinis dan faktor komorbid pasien serta jumlah dan kepekatan barium yang masuk ke saluran napas. Usia tua dan faktor komorbid dapat meningkatkan angka mortalitas. ${ }^{17}$ Jumlah aspirasi barium yang masuk ke saluran napas sangat mempengaruhi keparahan dan prognosis pasien. Pasien akan mengalami hipoksemia hingga gagal napas berat bila mengalami aspirasi barium dalam jumlah banyak. Sekret orofaring yang telah terdapat koloni bakteri, bila masuk ke saluran napas bercampur dengan kontras akan menyebabkan pneumonia bahkan sepsis bila tidak teratasi dengan baik. Selain itu, dengan semakin banyaknya partikel 
barium yang terakumulasi dalam intertisial paru, bila tidak tereliminasi maka dalam jangka panjang akan mengakibatkan terbentuknya fibrosis. ${ }^{13}$ Fibrosis yang luas akan menyebabkan gangguan restriksi paru sehingga menurunkan compliance paru. Untuk evaluasi jangka panjang aspirasi barium dan mengetahui luas fibrosis yang terjadi maka perlu dilakukan HRCT seperti terlihat pada gambar $7 .{ }^{11}$

\section{KESIMPULAN}

Telah dilaporkan sebuah kasus aspirasi barium pada pasien dengan keluhan batuk, tanpa disertai gejala sesak napas atau demam. Pasien memiliki riwayat tersedak dan batuk pada saat menelan bahan kontras barium sulfat untuk pemeriksaan esofagografi sesaat sebelum timbul keluhan. Dari foto toraks didapatkan gambaran opasitas hiperdens yang diduga sebagai kontras barium atau obstruksi yang sebagian besar berada pada lobus inferior paru kiri dengan jumlah yang sedikit. Pada perjalanannya pasien mengalami gejala infeksi seperti demam dan batuk disertai dahak berwarna putih yang menunjukkan bahwa pasien telah mengalami komplikasi pneumonia sehingga pasien mendapat antibiotik empiris broad-spectrum dengan Levofloxacin. Tindakan FOB dilakukan untuk menyedot kontras barium sebanyak mungkin yang masuk ke sistem bronko-alveolar dan untuk mengambil sampel pemeriksaan mikrobiologi. Satu minggu kemudian dilakukan evaluasi dan didapatkan perbaikan secara klinis, laboratoris dan radiologis.

\section{DAFTAR PUSTAKA}

1. Soedarsono. Pneumonia. Dalam Buku Ajar Ilmu Penyakit Paru 2010; Bagian Ilmu Penyakit Paru FK Unair-RSU Dr Soetomo. Surabaya.2010: 153-183.

2. IrwinRS.Aspiration.In:IrwinRS,CerraFB,RippeJM,eds.Irwinand Rippe's intensive care medicine. 4th ed. Vol. 1. Philadelphia: Lippincott Raven, 1999:685-92.

3. Torres A, Serra-Batlles J, Ferrer A. Severe community-acquired pneumonia: epidemiology and prognostic factors. Am Rev Respir Dis 1991;144:312-8

4. Pikus L, Levine MS, Yang TX, Rubestin SE, Katzka DA, Laufer I, Gefter WB. Videofluoroscopic studies of swallowing dysfunction and the relative risk of pneumonia. Am J Roentgenol 2003; 180:1613-16
5. Constantine K, Passakiotou M, Mouloudi E, Georgopoulou V, Gritsi-Gerogianni N. Severe barium sulphate aspiration: a report of two cases and review of the literature. Signa Vitae 2007;2(1):25-28

6. Franquet T, Gimenez A, Roson N, Torrubia S, Sabate JM, Perez C. Aspiration diseases: Findings, pitfalls, and differential diagnosis. Radiographics 2000;20:673-85

7. Gustafson yoshida N, Maglinte DD, Hamaker RCA, Kelvin FM. Evaluation of swallowing disorders: the modified barium swallow. Indiana Med Dec 1990;83(12):892-5.

8. Tamm I, Kortsik C. Severe barium sulphate aspiration into the lung: clinical presentation, prognosis and therapy. Respiration 1999;66:81-4.

9. Varatharaj A, Roome C, Allsup S. Barium aspiration. QJM, vol. 105, no. 9, pp. 903-904, 2012

10. Nelson SW, Christoforidis AJ, Pratt PC. Further experience with barium sulphate as a bronchographic contrast medium. Radiology 1976;92:367-70

11. Voloudaki A, Ergazakis N, Gourtsoyiannis N. Late changes in barium sulphate aspiration: HRCT features. ciliar;13:2226-9

12. Mendelson CL. The aspiration of stomach contents into the lungs during obstetric anesthesia. Am J Obstet Gynecol 1946;52:191205

13. Venkatraman B, Rehman HA, Abdul-Wahab A. High resolution computed tomography appearances oflate sequelae of barium aspiration in an asymptomatic young child. Saudi Med J 2005;26:665-7

14. Yunus F. Pneumokoniosis. Paru 1994;22-8

15. Ngurah Rai IB. Pneumokoniosis. Patogenesis dan gangguan fungsi. In: Abdullah A, Patau J, Susilo HJ, Saleh K, Tabri NA, Mappangara, et al. Naskah lengkap pertemuan ilmiah khusus (PIK) X Perhimpunan Dokter Paru Indonesia. Makassar: Subbagian paru Bagian Penyakit Dalam Fakultas Kedokteran Universitas Hasanuddin 2003. p. 183-216

16. Chiu CY, Wong KS, Tsai MH. Massive aspiration of barium sulfate during an upper gastrointestinal examination in a child with dysphagia. International Journal of Pediatric Otorhinolaryngology 2005; 69:541-544

17. C. Gray, S. Sivaloganathan, K.C. Simpkins. Aspiration of highdensity barium contrast medium causing acute pulmonary inflammation- report of two fatal cases in elderly women with disordered swallowing. Clin. Radiol. 1989; 40:397- 400.

18. Paul E, Marik M.B. Aspiration pneumonitis and aspiration pneumonia. N Engl J Med 2001;344:9

19. Bartlett JG, Gorbach SL, Finegold SM. The bacteriology of aspiration pneumonia. Am J Med 1974;56:202-7

20. Erondu Felix Okechukwu. Barium bronchogram following aspiration of contrast: a case report. Journal of Medicine and Medical Sciences 2012;3(11): 687-691

21. Trate DM, Parkman HP, Fisher RS. Dysphagia. Evaluation, diagnosis and treatment. Primary care 1996;2393:417

22. Rasley A, Logemann JA, Kahrilas PJ, Rademaker AW, Pauloski BR, Dodds WJ. Prevention of barium aspiration during videofloroscopic swallowing studies: value of change in posture. AJR Am J Roentgenol 1993;160(5):1005-1009. 